Article

\title{
Expanding Current Knowledge on the Chemical Composition and Antioxidant Activity of the Genus Lactarius
}

\author{
Vanessa Vieira $^{1,2}$, Lillian Barros ${ }^{1, *}$, Anabela Martins ${ }^{2}$ and Isabel C. F. R. Ferreira ${ }^{1,2, *}$ \\ 1 Centro de Investigação de Montanha (CIMO), ESA, Instituto Politécnico de Bragança, \\ Campus de Santa Apolónia, Apartado 1172, 5301-855 Bragança, Portugal; \\ E-Mail: vieira.aa.vanessa@gmail.com
}

2 School of Agriculture, Polytechnic Institute of Bragança, Campus de Santa Apolónia, Ap. 1172, 5301-855 Bragança, Portugal; E-Mail: amartins@ipb.pt

* Authors to whom correspondence should be addressed; E-Mails: 1illian@ipb.pt (L.B.); iferreira@ipb.pt (I.C.F.R.F); Tel.: +351-273-303-903 (L.B.); +351-273-303-219 (I.C.F.R.F); Fax: +351-273-325-405 (L.B \& I.C.F.R.F).

External Editor: Nancy D. Turner

Received: 6 November 2014; in revised form: 4 December 2014 / Accepted: 4 December 2014 / Published: 10 December 2014

\begin{abstract}
Despite the presence of toxic compounds in inedible mushrooms, the question whether the chemical nutrients and non-nutrients compositions in edible and inedible Lactarius species are similar remains unanswered. To answer this question, Lactarius citriolens Pouzar and Lactarius turpis (Weinm.) Fr., two inedible species, were studied in order to obtain information about their chemical composition and bioactivity. Free sugars, fatty acids, tocopherols, organic and phenolic acids were analysed by chromatographic techniques coupled to different detectors. L. citriolens and L. turpis methanolic extracts were tested regarding antioxidant potential (reducing power, radical scavenging activity and lipid peroxidation inhibition). The composition of macronutrients varied among the two species, but the profiles were similar between them and among other Lactarius species; L. citriolens gave the highest energy contribution, saturated fatty acids and organic acids, while the L. turpis sample was richer in free sugars, mono- and polyunsaturated fatty acids, tocopherols and phenolic compounds. L. turpis methanolic extract showed the highest antioxidant activity. The absence of hepatoxicity of the methanolic extracts was confirmed in porcine liver primary cells (in vitro conditions). The present study provided new information about wild L. citriolens and L. turpis, comparing their chemical
\end{abstract}


composition and antioxidant properties with other Lactarius species, and expanding the knowledge about this genus.

Keywords: Lactarius citriolens; Lactarius turpis; wild mushrooms; chemical composition; antioxidant activity

\section{Introduction}

Wild mushrooms have become more important in our diet for their nutritional [1], organoleptic [2] and medicinal [3] characteristics. The scientific community has studied several mushroom species in order to develop new therapies $[3,4]$. In fact, they contain a large diversity of compounds with a wide range of nutritional and health benefits such as stimulation of the immune system, providing an anti-cancer function as well as controlling blood lipids in humans [1,3]. The nutraceuticals present in mushrooms have been related with their antioxidant activity [4].

Lactarius, popularly known as "milk cap", is one of the larger genera of ectomycorrhizal Basidiomycota, with about 400 species recognized worldwide. Members of the genus are reported in association with numerous trees and shrubs [5]. One particular character of the genus Lactarius is that all species exude a typical milky fluid when their basidiocarps are broken. This milky fluid or latex may taste mild or acrid and may be white or colored or may have a changing color depending on the species, providing important taxonomical information [6]. They are considered medicinal and nutritionally important and promising mushrooms [3,4].

Lactarius citriolens Pouzar and Lactarius turpis (Weinm.) Fr. are inedible species that occur in Bragança, Northeastern of Portugal, and there is not much information about them. Concerning L. turpis, there are some studies reporting lead, cadmium and mercury contents [7], antifungal activity against Penicillium expansum [8], identification of necatorone (an alkaloid pigment) [9], tolerance to toxic metal minerals [10], and determination of isotope activity (e.g., radiocesium) from contaminated areas [11]. However, nothing has been reported on its chemical composition and bioactivity. Regarding L. citriolens, as far as we know, only phylogenetic studies are available in the literature [12].

Our research group has published several works that intend to contribute to inventorying and documenting the chemical and antioxidant properties of wild mushrooms from Northeastern Portugal (including different Lactarius species) [13-15]. The present work aims to expand the knowledge on the Lactarius genus by presenting a detailed chemical characterization of L. citriolens and L. turpis, including evaluation of nutrients (e.g. macronutrients, free sugars, fatty acids and tocopherols), non-nutrients (e.g. phenolic compounds and organic acids) and antioxidant activity of their methanolic extracts (e.g. reducing power, radical-scavenging activity and inhibition of lipid peroxidation). The confirmation of non-toxicity of the extracts was performed in a primary cell culture of porcine liver cells. 


\section{Results and Discussion}

\subsection{Chemical Composition of the Fruiting Bodies}

The macronutrients composition of L. citriolens and L. turpis fruiting bodies is presented in Table 1. L. turpis showed the highest level of proteins, ash and carbohydrates, however, the energetic contribution of $L$. citriolens was superior, due to its higher fat content. It was possible to find some reports about other species of the same genus, namely L. deliciosus [15-23], L. hatsudake [19], L. piperatus [16], L. quieticolor [24], L. salmonicolor [13,21], L. sanguifluus [23,25], L. semisanguifluus [23] and L. volemus [19]. All of these species also presented carbohydrates and proteins as major macronutrients, and some of them similar energetic contributions (317-389 kcal/100 g dry weight) $[13,15]$.

Table 1. Macronutrients, free sugars, fatty acids and tocopherols of the fruiting bodies expressed in dry weight basis (mean $\pm \mathrm{SD}$ ).

\begin{tabular}{cccc}
\hline Parameter & Lactarius citriolens & Lactarius turpis & t-Student Test $\boldsymbol{p}$-value \\
\hline Fat $(\mathrm{g} / 100 \mathrm{~g})$ & $5.37 \pm 0.30$ & $2.06 \pm 0.27$ & $<0.001$ \\
Proteins $(\mathrm{g} / 100 \mathrm{~g})$ & $10.89 \pm 0.33$ & $13.06 \pm 0.29$ & $<0.001$ \\
Ash $(\mathrm{g} / 100 \mathrm{~g})$ & $6.99 \pm 0.23$ & $7.21 \pm 0.12$ & 0.109 \\
Carbohydrates $(\mathrm{g} / 100 \mathrm{~g})$ & $76.76 \pm 0.35$ & $77.68 \pm 0.35$ & 0.033 \\
Energy $(\mathrm{kcal} / 100 \mathrm{~g})$ & $398.89 \pm 1.74$ & $381.47 \pm 1.29$ & $<0.001$ \\
\hline Mannitol $(\mathrm{g} / 100 \mathrm{~g})$ & $8.31 \pm 0.30$ & $19.21 \pm 0.45$ & $<0.001$ \\
Trehalose $(\mathrm{g} / 100 \mathrm{~g})$ & $0.45 \pm 0.01$ & $0.33 \pm 0.03$ & $<0.001$ \\
Total sugars $(\mathrm{g} / 100 \mathrm{~g})$ & $8.76 \pm 0.29$ & $19.54 \pm 0.47$ & $<0.001$ \\
\hline $\mathrm{C} 16: 0$ & $5.35 \pm 0.01$ & $8.02 \pm 0.09$ & $<0.001$ \\
$\mathrm{C} 18: 0$ & $40.58 \pm 0.41$ & $12.60 \pm 0.83$ & $<0.001$ \\
C18:1n9 & $25.00 \pm 0.78$ & $26.29 \pm 0.98$ & 0.065 \\
C18:2n6 & $22.46 \pm 0.03$ & $48.55 \pm 0.14$ & $<0.001$ \\
SFA (relative percentage) & $51.85 \pm 0.70$ & $23.73 \pm 1.00$ & $<0.001$ \\
MUFA (relative percentage) & $25.42 \pm 0.78$ & $27.18 \pm 0.98$ & 0.026 \\
PUFA (relative percentage) & $22.74 \pm 0.08$ & $49.09 \pm 0.01$ & $<0.001$ \\
\hline$\alpha$-tocopherol $(\mu \mathrm{g} / 100 \mathrm{~g})$ & $20.43 \pm 1.27$ & $45.84 \pm 5.61$ & $<0.001$ \\
$\beta$-tocopherol $(\mu \mathrm{g} / 100 \mathrm{~g})$ & $70.65 \pm 7.45$ & $14.79 \pm 1.54$ & $<0.001$ \\
$\gamma$-tocopherol $(\mu \mathrm{g} / 100 \mathrm{~g})$ & $4.69 \pm 0.70$ & $72.32 \pm 7.44$ & $<0.001$ \\
$\delta$-tocopherol $(\mu \mathrm{g} / 100 \mathrm{~g})$ & $5.28 \pm 0.42$ & $\mathrm{nd}$ & - \\
Total tocopherols $(\mu \mathrm{g} / 100 \mathrm{~g})$ & $101.05 \pm 7.30$ & $132.94 \pm 11.50$ & $<0.001$ \\
\hline
\end{tabular}

nd-not detected. Main fatty acids: C16:0 (palmitic acid), C18:0 (stearic acid), C18:1n9 (oleic acid) and C18:2n6 (linoleic acid); 20 more fatty acids were identified in trace amounts. SFA-saturated fatty acids; MUFA-monounsaturated fatty acids; PUFA-polyunsaturated fatty acids.

Observing the macronutrient profile of the genus it can be concluded that the two studied species have similar characteristics to the edible species. However, since there are reports of the presence of necatorin, a highly mutagenic compound, in L. turpis, [26], and the possibility of poisoning which manifests by stomach and intestinal troubles [27], L. turpis is nowadays considered non-edible [28]. 
Regarding L. citriolens, although this species is rarely found, it should be consumed with caution given the lack of information [28].

Analyzing the free sugars composition, mannitol and trehalose were detected in both samples (Table 1; Figure 1A). L. turpis and L. citriolens revealed the highest content in mannitol and trehalose, respectively. L. turpis gave the highest content in total free sugars. As far as we know, there are only some Portuguese studies, all of them from our research group, on the free sugars in Lactarius spp., namely in L. bertillonii [29], L. deliciosus [15-18], L. hepaticus [30], L. piperatus [16], L. quietus [14], L. salmonicolor [13] and L. vellereus [29]. All the mentioned species presented mannitol and trehalose, with the exception of the report of Fernandes et al. [15] who also found fructose, but in this case in lower amounts $(0.18 \mathrm{~g} / 100 \mathrm{~g}$ dry weight). In fact, mannitol, a sugar alcohol, and trehalose, an oligosaccharide, are the main representatives sugars present in mushrooms $[1,16]$. Mannitol, has half the calories of sucrose and because of their mannitol contents, mushrooms are useful for diabetic patients [31]. Trehalose is a common sugar component of most immature sporocarps and it may function as a reserve material, which can be metabolised when the sporocarps are maturing [32].

The fatty acids quantified in higher amounts in both species were palmitic (C16:0), stearic (C18:0), oleic (C18:1n9) and linoleic (C18:2n6) acids (Table 1; Figure 1B). Concerning saturated fatty acids (SFA), palmitic acid was found in higher percentages in L. turpis, while stearic acid was presented in higher percentages in L. citriolens. Oleic acid (monounsaturated fatty acid-MUFA) and linoleic acid (polyunsaturated fatty acid-PUFA) were found in higher percentages in L. turpis.

Figure 1. Individual profile in sugars (A) of L. turpis: 1-mannitol, 2-trehalose, 3-raffinose (IS); fatty acids (B) of L. citriolens: 1-caproic acid (C6:0); 2-caprylic acid (C8:0); 3-capric acid (C10:0); 4-lauric acid (C12:0); 5-myristic acid (C14:0); 6-myristoleic acid (C14:1); 7-pentadecanoic acid (C15:0); 8-palmitic acid (C16:0); 9-palmitoleic acid (C16:1); 10-heptadecanoic acid (C17:0); 11-stearic acid (C18:0); 12-oleic acid (C18:1n9c); 13-linoleic acid (C18:2n6c); 14- $\alpha$-linolenic acid (C18:3n3c); 15-arachidic acid (C20:0); 16-eicosenoic acid (C20:1c); 17-cis-11,14-eicosadienoic acid (C20:2c); 18-cis-11,14,17eicosatrienoic acid and heneicosanoic acid (C20:3n3 + C21:0); 19-cis-5,8,11,14,17eicosapentaenoic acid (C20:5n3); 20-behenic acid (C22:0); 21-tricosanoic acid (C23:0); 22-lignoceric acid (C24:0); 23-nervonic acid (C24:1); and tocopherols (C) of L turpis: 1- $\alpha$-tocopherol, 2-BHT, 3- $\beta$-tocopherol, 4- $\gamma$-tocopherol, 5-tocol (IS). MP-mobile phase.

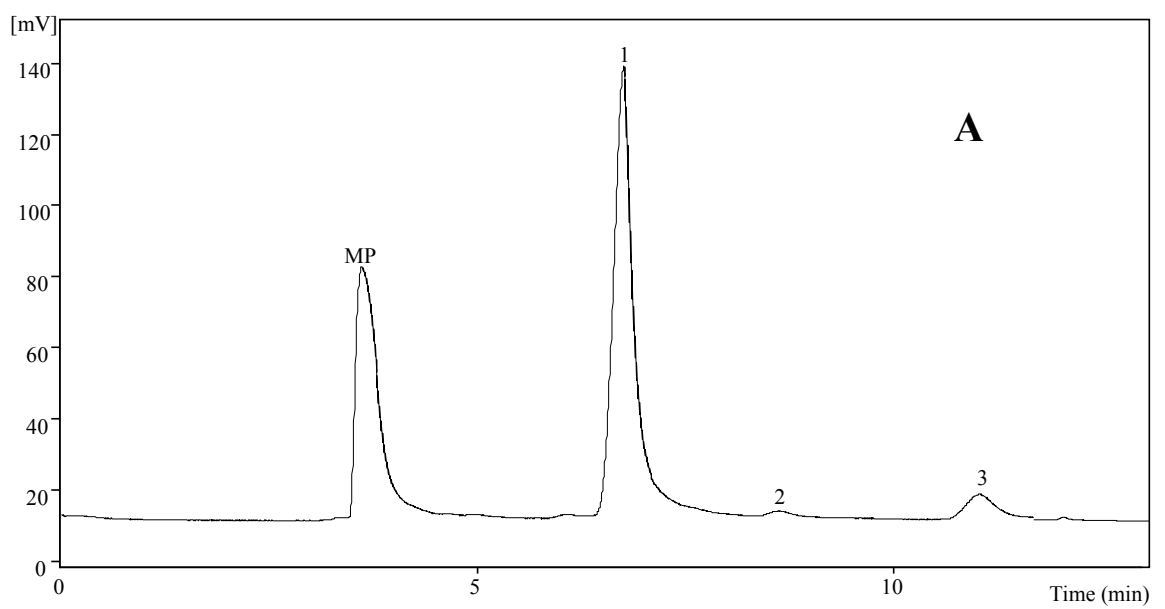


Figure 1. Cont.
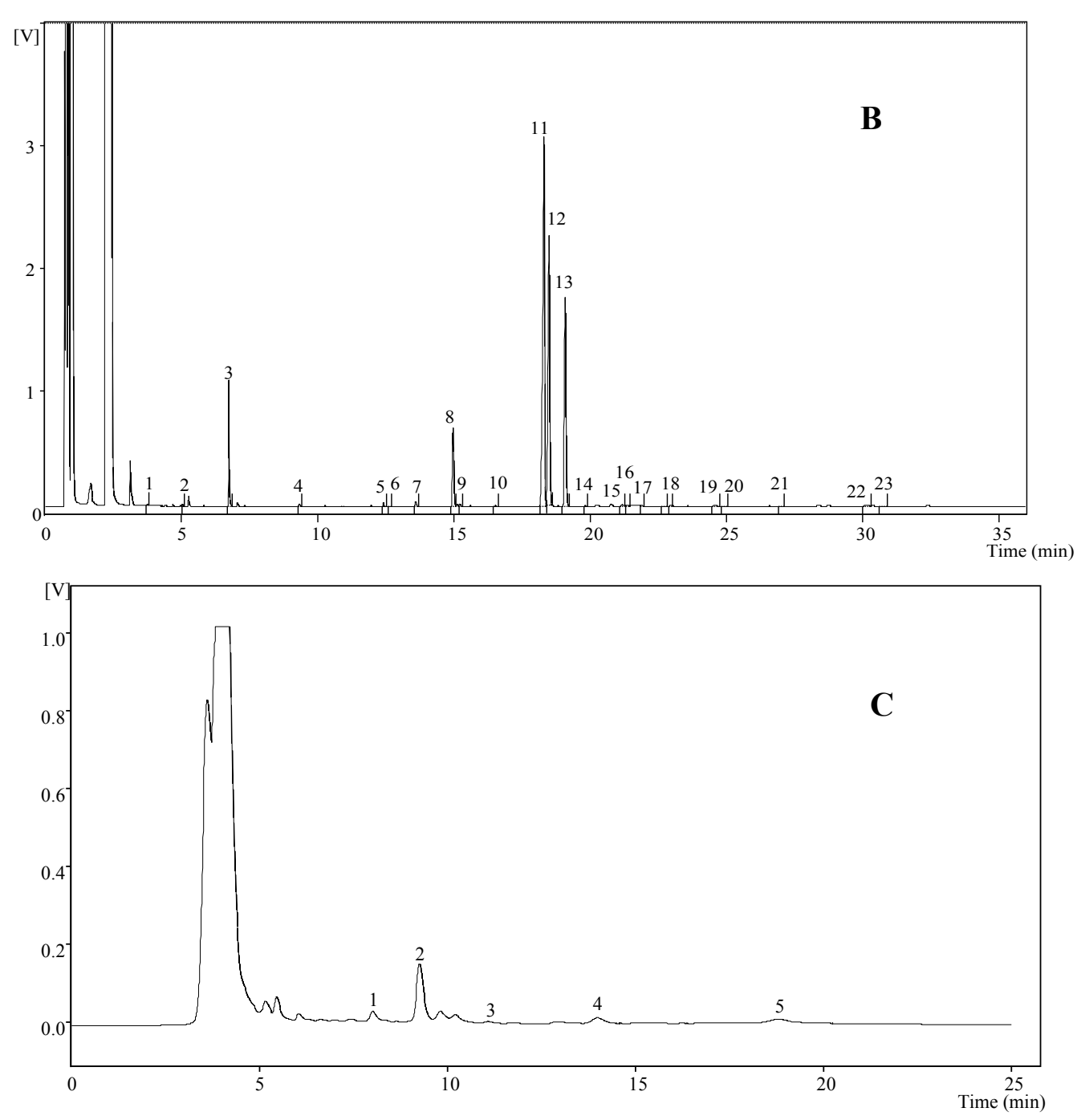

The L. citriolens sample was richer in SFA, however the L. turpis sample presented the highest level of MUFA and PUFA. Like L. citriolens, there are other Lactarius species with stearic acid (C18:0) as the main fatty acid present, namely L. aurantiacus [33], L. bertillonii [29], L. deliciosus [15,16,34], L. salmonicolor [13], L. piperatus [16] and L. vellereus [29]. However, linoleic acid (C18:2) is the major fatty acid in other Lactarius species, as occurred in the herein studied L. turpis sample, L. deliciosus [23,25], L. hepaticus [30], L. quietus [14], L. rufus [35], L. salmonicolor [36], L. sanguifluus [23,25], L. semisanguifluus [23], L. thejogalus [35], L. volemus [14]. Only one report mentioned oleic acid as the main fatty acid, and it was in a L. delicious sample from Portugal [18]. Stearic acid is proved to have a high antibacterial activity since it presents a strong efficacy against Gram-positive and Gram-negative bacteria [37]. Linoleic acid is known as precursor of 1-octen-3-ol, the alcohol of fungi, which is the principal aromatic compound in most fungi [2].

Concerning tocopherols, both samples presented $\alpha$-, $\beta$ - and $\gamma$-isoforms (Table 1; Figure 1C). The $\alpha$ - and $\gamma$-isoforms were the most abundant in L. turpis. On the other hand, $\beta$-tocopherol was present in higher amounts in L. citriolens. This was also the only sample presenting $\delta$-tocopherol. It was L. turpis that revealed the highest content of total tocopherols. To our knowledge, there are only Portuguese studies presenting tocopherols content in Lactarius spp. The main isoform was variable, 
and the total content reported varied between $15 \mu \mathrm{g} / 100 \mathrm{~g}$ to $316 \mu \mathrm{g} / 100 \mathrm{~g}[29,38]$. Besides preventing lipid peroxidation, vitamin $\mathrm{E}$ appears to exert effects on other cardiovascular risk factors including reduction of platelet adhesion and aggregation [39].

Regarding the organic acids profile, it was possible to identify and quantify four different compounds (Table 2; Figure 2A), namely oxalic, quinic, malic and fumaric acids. The wild mushroom L. turpis was the one that revealed the highest concentration of oxalic acid, while L. citriolens presented the highest malic and fumaric acids content. Quinic acid was only present in L. citriolens and this mushroom also showed the highest content in total organic acids.

Table 2. Organic acids and phenolic compounds of the fruiting bodies expressed in dry weight basis (mean $\pm \mathrm{SD})$.

\begin{tabular}{cccc}
\hline Compound & Lactarius citriolens & Lactarius turpis & t-Student test $\boldsymbol{p}$-value \\
\hline Oxalic acid $(\mathrm{g} / 100 \mathrm{~g})$ & $0.06 \pm 0.01$ & $0.10 \pm 0.01$ & $<0.001$ \\
Quinic acid $(\mathrm{g} / 100 \mathrm{~g})$ & $0.18 \pm 0.06$ & $\mathrm{nd}$ & - \\
Malic acid $(\mathrm{g} / 100 \mathrm{~g})$ & $3.36 \pm 0.03$ & $2.96 \pm 0.19$ & 0.008 \\
Fumaric acid $(\mathrm{g} / 100 \mathrm{~g})$ & $0.50 \pm 0.02$ & $0.24 \pm 0.00$ & $<0.001$ \\
Total organic acids $(\mathrm{g} / 100 \mathrm{~g})$ & $4.10 \pm 0.06$ & $3.30 \pm 0.19$ & $<0.001$ \\
\hline Gallic acid $(\mathrm{mg} / 100 \mathrm{~g})$ & $\mathrm{nd}$ & $0.08 \pm 0.00$ & - \\
p-Hydroxybenzoic acid $(\mathrm{mg} / 100 \mathrm{~g})$ & $0.15 \pm 0.01$ & $0.12 \pm 0.00$ & 0.002 \\
Total phenolic acids $(\mathrm{mg} / 100 \mathrm{~g})$ & $0.15 \pm 0.01$ & $0.20 \pm 0.01$ & $<0.001$ \\
Cinnamic acid $(\mathrm{mg} / 100 \mathrm{~g})$ & $0.15 \pm 0.00$ & $0.12 \pm 0.00$ & $<0.001$ \\
\hline & nd-not detected. &
\end{tabular}

As far as we know, there are only two reports concerning organic acids in Lactarius spp. namely, L. deliciosus from different locations within Portugal and L. volemus, with malic acid as the main organic acid present [40,41].

Concerning phenolic acids, the studied samples revealed the presence of gallic and p-hydroxybenzoic acids, and also the related compound cinnamic acid (Table 2; Figure 2B). Gallic acid was only found in L. turpis. However, it was L. citriolens that presented the highest amounts of $p$-hydroxybenzoic acid and of the related compound cinnamic acid. Analyzing these results we can conclude that the wild L. turpis sample was richer in phenolic acids compared to L. citriolens. It is difficult to establish a profile for the genus as for what concerns phenolic compounds. In fact, the phenolic compounds recorded in different species are not the same and the main phenolic compounds also vary among different species. For example, $p$-hydroxybenzoic acid was the main phenolic acid in L. deliciosus [42], L. salmonicolor [43] and L. volemus [14]. However, o-coumaric [23], homogentisic [44] and tannic [45] acids were also reported as the main phenolic compounds in L. deliciosus and L. volemus samples. For L. volemus, protocatechuic acid was also reported as the main phenolic acid [46]. The same phenolic acid was in major abundance in L. vellereus [29]; catechin was also found in L. deterrimus [47] and L. vellereus [48]; and $o$-coumaric was the major phenolic acid in L. semisanguifluus [23]. p-OH-Phenylacetic acid was the main phenolic acid in L. sanguifluus [23], however Puttaraju et al. [45] reported tannic acid as the principal compound for the same species. Regarding the related compound cinnamic acid, it was found in L. aurantiacus [43], L. bertillonii [29] 
and L. quietus [14]. In fact, Lactarius spp. is a genus rich in phenolic compounds, which have been reported to display different health benefits.

Figure 2. Individual profile in organic acids (A) of L. citriolens: 1-oxalic acid, 2-quinic acid, 3-malic acid, 4-fumaric acid; and phenolic acids (B) of L. turpis: 1-gallic acid; 2-p-hydroxybenzoic acid; 3-cinnamic acid. MP-mobile phase.
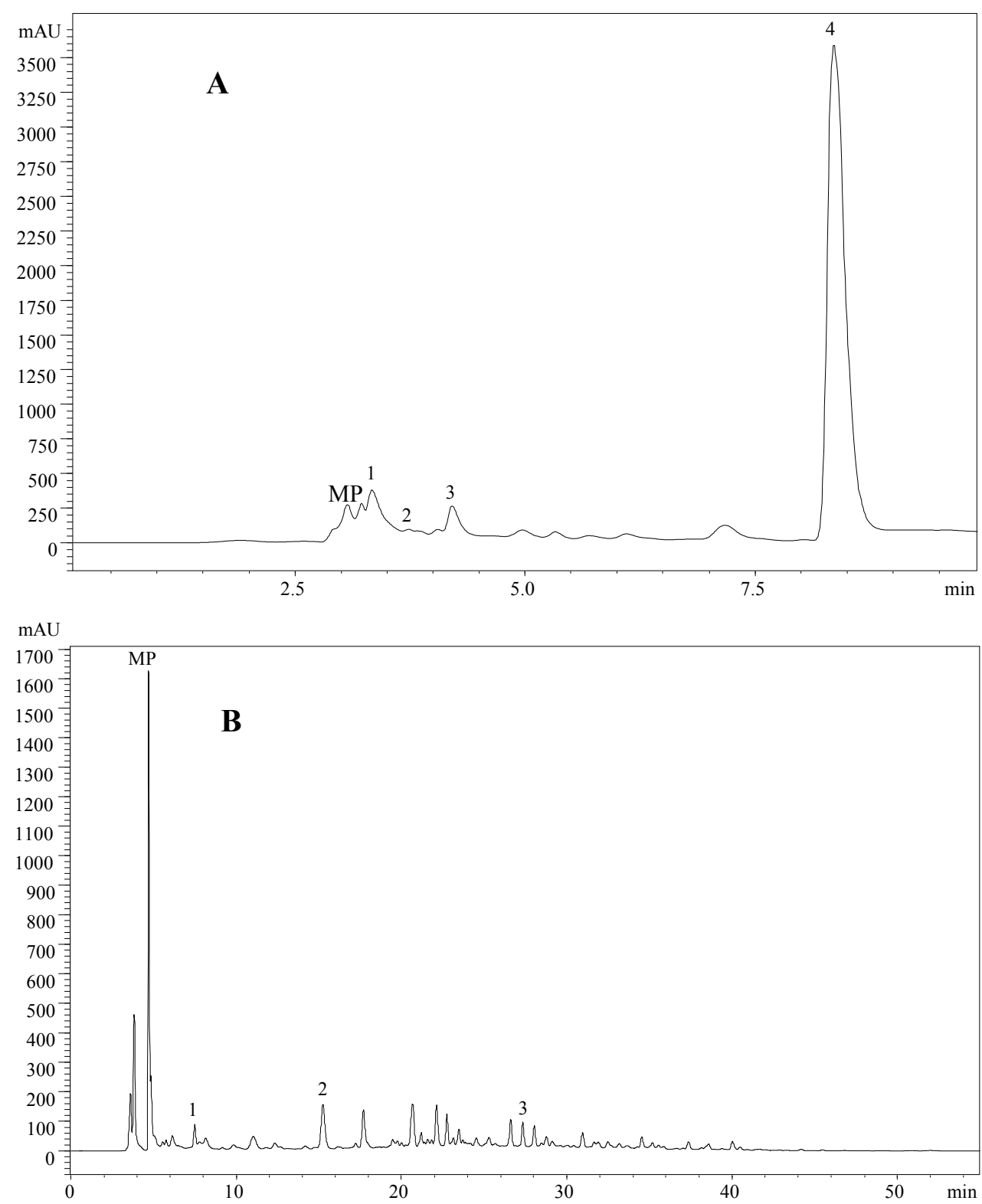

\subsection{Antioxidant Activity of the Methanolic Extracts and Confirmation of Non-Toxicity}

Analyzing the results of the antioxidant potential (Table 3), L. turpis methanolic extract revealed the highest reducing power evaluated through the Folin-Ciocalteu and ferricyanide/Prussian blue assays. The same sample also revealed the highest radical scavenging activity, since it presented the lowest $\mathrm{EC}_{50}$ value for DPPH assay. L. turpis also showed the highest lipid peroxidation inhibition in the $\beta$-carotene/linoleate and TBARS assays. 
Table 3. Antioxidant activity of the methanolic extracts (mean \pm SD).

\begin{tabular}{|c|c|c|c|c|}
\hline $\begin{array}{l}\text { Antioxidant } \\
\text { Activity }\end{array}$ & Assay & $\begin{array}{l}\text { Lactarius } \\
\text { citriolens }\end{array}$ & $\begin{array}{c}\text { Lactarius } \\
\text { turpis }\end{array}$ & $\begin{array}{c}t \text {-Student } \\
\text { Test } p \text {-Value }\end{array}$ \\
\hline \multirow{2}{*}{ Reducing power } & $\begin{array}{c}\text { Folin-Ciocalteu (mg } \\
\text { GAE/g extract) }\end{array}$ & $13.13 \pm 0.17$ & $22.02 \pm 0.09$ & $<0.001$ \\
\hline & $\begin{array}{l}\text { Ferricyanide/Prussian } \\
\text { blue }\left(\mathrm{EC}_{50} ; \mathrm{mg} / \mathrm{mL}\right)\end{array}$ & $2.61 \pm 0.13$ & $1.53 \pm 0.02$ & $<0.001$ \\
\hline $\begin{array}{c}\text { Radical scavenging } \\
\text { activity }\end{array}$ & $\begin{array}{c}\text { DPPH scavenging } \\
\text { activity }\left(\mathrm{EC}_{50} ; \mathrm{mg} / \mathrm{mL}\right)\end{array}$ & $15.77 \pm 0.27$ & $4.18 \pm 0.04$ & $<0.001$ \\
\hline \multirow{2}{*}{$\begin{array}{l}\text { Lipid peroxidation } \\
\text { inhibition }\end{array}$} & $\begin{array}{l}\beta \text {-Carotene } / \text { linoleate } \\
\quad\left(\mathrm{EC}_{50} ; \mathrm{mg} / \mathrm{mL}\right)\end{array}$ & $6.21 \pm 0.24$ & $4.92 \pm 0.27$ & $<0.001$ \\
\hline & TBARS $\left(\mathrm{EC}_{50} ; \mathrm{mg} / \mathrm{mL}\right)$ & $0.82 \pm 0.03$ & $0.57 \pm 0.02$ & $<0.001$ \\
\hline
\end{tabular}

Concerning the Folin-Ciocalteu assay, higher values mean higher reducing power (GAE-gallic acid equivalents); for the other assays, the results are presented in $\mathrm{EC}_{50}$ values, what means that higher values correspond to lower reducing power or antioxidant potential. $\mathrm{EC}_{50}$ : Extract concentration corresponding to $50 \%$ of antioxidant activity or 0.5 of absorbance for the Ferricyanide/Prussian blue assay.

The highest total antioxidant activity in the genus, measured through Folin-Ciocalteu assay, was reported by Orhan and Üstün [49] in a L. deliciosus sample (51.27 mg GAE/g). L. deliciosus $\left(\mathrm{EC}_{50}=500 \mu \mathrm{g} / \mathrm{mL}\right.$; [49] $)$ and L. bertillonii $\left(\mathrm{EC}_{50}=1.63 \mathrm{mg} / \mathrm{mL}\right.$; [29]) gave the highest reducing power. Regarding radical scavenging activity, the highest capacity was described by Unekwu et al. [50] for a $L$. deliciosus sample $\left(\mathrm{EC}_{50}=300 \mu \mathrm{g} / \mathrm{mL}\right)$. Finally, regarding the lipid peroxidation inhibition, the highest antioxidant activity was obtained in L. deliciosus ( $\mathrm{IC}_{50}=148.0 \mu \mathrm{g} / \mathrm{mL}$ ) measured by $\beta$-carotene/linoleate assay [34] and L. bertillonii $\left(\mathrm{EC}_{50}=1.21 \mathrm{mg} / \mathrm{mL}\right)$ through TBARS assay [29]. Both of our samples present lower $\mathrm{EC}_{50}$ values in the TBARS assay being L. turpis the species with the highest antioxidant potential of the genus measured by this biochemical assay. Antioxidants can help the endogenous defense system, playing an important role as potential protective agents, reducing oxidative damage by free radicals so, preventing events related to aging and diseases, such as atherosclerosis, diabetes, cancer and cirrhosis [4].

As the methanolic extracts displayed antioxidant activity, it was important to evaluate their cytotoxicity against liver cells, which are considered the best in vitro model for studies of human cytotoxicity. Despite of the reported presence of toxic compounds in L. turpis fruiting bodies, the prepared extracts did not reveal any toxicity in PLP2 liver primary culture; the positive control ellipticine gave a GI50 (sample concentration that inhibited $50 \%$ of the net cell growth) $=2.06 \pm 0.03 \mu \mathrm{g} / \mathrm{mL}$. This could indicate that the toxic compounds were not present in these extracts. Nevertheless, it should be highlighted that an in vitro assay was performed, and that under in vivo conditions the microbiota that inhabit our intestines can readily convert molecules, some of which becoming toxic.

\section{Experimental Section}

\subsection{Sampling of Mushroom Species}

Lactarius citriolens Pouzar and Lactarius turpis (Weinm.) Fr. samples were collected in Bragança (Northeastern Portugal), in November 2012. The authentications were done at the Polytechnic Institute 
of Bragança. Voucher specimens were deposited at herbarium of School of Agriculture of Polytechnic Institute of Bragança, Portugal. The samples were immediately lyophilised (FreeZone 4.5, Labconco, Kansas City, MO, USA), reduced to a fine dried powder (20 mesh), mixed to obtain a homogeneous sample and stored in a desiccator, protected from light, until further analysis.

\subsection{Chemical Composition of L. citriolens and L. turpis Fruiting Bodies}

\subsubsection{Macronutrients.}

The samples were analysed for moisture, proteins, fat, carbohydrates and ash using the standard procedures [51]. The crude protein content $(\mathrm{N} \times 4.38)$ of the samples was estimated by the macro-Kjeldahl method; the crude fat was determined by extracting a known weight of powdered sample with petroleum ether, using a Soxhlet apparatus; the ash content was determined by incineration at $600 \pm 15^{\circ} \mathrm{C}$. Total carbohydrates were calculated by difference. Energy was calculated according to the following equation: Energy $(\mathrm{kcal})=4 \times(\mathrm{g}$ protein $+\mathrm{g}$ carbohydrate $)+9 \times(\mathrm{g}$ fat $)$.

\subsubsection{Individual Compounds}

Free sugars were determined by a high performance liquid chromatograph (HPLC) system coupled to a refraction index (RI) detector as previously described by the authors [13]. Fatty acids were determined after a transesterification procedure as described previously by the authors [13]. The fatty acids profile was analyzed using a gas chromatographer equipped with a flame ionization detector (GC-FID). Tocopherols were determined following a procedure previously described by the authors [13]. Analysis was performed by HPLC (equipment described above), and a fluorescence detector. Organic acids were determined by ultra-fast liquid chromatography (UFLC) coupled with a photodiode array detector (PDA) as previously described by the authors [41]. Phenolic acids determination was performed using the UFLC mentioned above, as previously described by Barros et al. [42].

\subsection{Bioactivity of L. citriolens and L. turpis Methanolic Extracts}

\subsubsection{Extract Preparation}

Each lyophilized sample ( $1 \mathrm{~g})$ was extracted by stirring with methanol $(40 \mathrm{~mL})$ for $1 \mathrm{~h}$ and subsequently filtered through Whatman No. 4 paper. The residue was then extracted with methanol $\left(20 \mathrm{~mL}\right.$ ) for $1 \mathrm{~h}$. The combined methanolic extracts were evaporated at $40{ }^{\circ} \mathrm{C}$ (Büchi R-210 rotary evaporator, Flawil, Switzerland) to dryness and re-dissolved in: (a) methanol for antioxidant activity assays $(20 \mathrm{mg} / \mathrm{mL})$ and (b) distillated water for the toxicity assay in porcine liver primary cells $(8 \mathrm{mg} / \mathrm{mL})$.

\subsubsection{Antioxidant Activity Assays}

The antioxidant activity of the methanolic extracts was evaluated by DPPH radical-scavenging activity, reducing power (Folin-Ciocalteu and ferricyanide/Prussian blue assays), inhibition of $\beta$-carotene bleaching in the presence of linoleic acid radicals and inhibition of lipid peroxidation using TBARS in brain homogenates. Trolox was used as positive control [13]. 


\subsubsection{Toxicity for Porcine Liver Cells}

The assay was performed with a cell culture prepared from a freshly harvested porcine liver (PLP2), and by applying sulphorhodamine assay. A complete procedure was previously described by the authors [52]. Ellipticine was used as positive control.

\subsection{Statistical Analysis}

Three samples were used for each preparation and all the assays were carried out in triplicate. The results are expressed as mean values and standard deviation (SD). The results were analyzed using a t-student test and this treatment was carried out using the SPSS v. 22.0 program.

\section{Conclusions}

Overall, L. citriolens revealed the highest energetic contribution, saturated fatty acids content and organic acids concentration, while L. turpis was richer in free sugars, mono- and polyunsaturated fatty acids, tocopherols and phenolic compounds. L. turpis methanolic extract showed the highest antioxidant activity in all the in vitro assays. The studied extracts did not show toxicity in porcine liver primary cells. The edible species of the Lactarius genus are considered healthy foods due to their low content in calories and fat, but richness in proteins and carbohydrates. The macronutrients profiles of L. citriolens and L. turpis are similar to the ones reported for those edible species, despite the presence of some toxic compounds that make them not recommended for consumption. Nevertheless, they contain several interesting molecules with bioactive potential, namely antioxidant activity, which can be isolated to be used in drugs or nutraceuticals. This study provides new data concerning chemical characterization and bioactivity of L. citriolens and L. turpis.

\section{Acknowledgments}

The authors are grateful to Fundação para a Ciência e Tecnologia (FCT, Portugal) and COMPETE/QREN/EU for financial support to L. Barros and CIMO (strategic project PEst-OE/AGR/UI0690/2011).

\section{Author Contributions}

Conducted bibliographic research and data organization: Vanessa Vieira and Lillian Barros; Conducted the nutritional value, lipophilic and hydrophilic compounds analysis, and the antioxidant activity assays: Vanessa Vieira, Lillian Barros and Isabel C.F.R. Ferreira; Conducted the samples collection and preparation: Vanessa Vieira and Anabela Martins; Wrote or contributed to the writing of the manuscript: Vanessa Vieira and Isabel C.F.R. Ferreira; Revised the manuscript writing: Anabela Martins and Isabel C.F.R Ferreira.

\section{Conflicts of Interest}

The authors declare no conflict of interest. 


\section{References}

1. Kalac, P. Chemical composition and nutritional value of European species of wild growing mushrooms: A review. Food Chem. 2009, 113, 9-16.

2. Maga, J.A. Mushroom flavor. J. Agric. Food Chem. 1981, 29, 1-4.

3. Joshi, S.; Vishwakarma, M.P.; Mahar, R.; Bhatt, R.P. Medicinally important and edible species of genus Lactarius from Garhwal Himalaya, India. Mycosphere 2013, 4, 714-720.

4. Ferreira, I.C.F.R.; Barros, L.; Abreu, R.M.V. Antioxidants in wild mushrooms. Curr. Med. Chem. 2009, 16, 1543-1560.

5. Nuytinck, J.; Verbeken, A.; Rinaldi, A.C.; Leonardi, M.; Pacioni, C.; Comandini, O. Characterization of Lactarius tesquorum ectomycorrhizae on Cistus sp. and molecular phylogeny of related European Lactarius taxa. Mycologia 2004, 96, 272-282.

6. Heilmann-Clausen, J.; Verbeken, A.; Vesterholt, J. The Genus Lactarius-Fungi of Northern Europe. In Danish Mycological Society, 2nd; NHBS: Devon, UK, 1998.

7. Liukkonen-Lilja, H.; Kuusi, T.; Laaksovirta, K.; Lodenius, M.; Piepponen, S. The effect of lead processing works on the lead, cadmium and mercury contents of fungi. Z. Lebensm.-Unters. Forsch. 1983, 176, 120-123.

8. Florianowicz, T. Inhibition of growth and sporulation of Penicillium expansum by extracts of selected Basidiomycetes. Acta Soc. Botan. Pol. 2000, 69, 263-267.

9. Fugmann, B.; Steffan, B.; Steglich, W. Necatorone, an alkaloidal pigment from the gilled toadstool Lactarius necator (agaricales). Tetrahedron Lett. 1984, 25, 3575-3578.

10. Fomina, M.A.; Alexander, I.J.; Colpaert, J.V.; Gadd, G.M. Solubilization of toxic metal minerals and metal tolerance of mycorrhizal fungi. Soil Biol. Biochem. 2005, 37, 851-866.

11. Lux, D.; Kammerer, L.; Riihm, W.; Wirth, E. Cycling of Pu, Sr, Cs, and other longliving radionuclides in forest ecosystems of the $30-\mathrm{km}$ zone around Chernobyl. Sci. Total Environ. 1995, $173,375-384$.

12. Verbeken, A.; Stubbe, D.; van de Putte, K.; Eberhardt, U.; Nuytinck, J. Tales of the unexpected: angiocarpous representatives of the Russulaceae in tropical South East Asia. Persoonia 2014, 32, $13-24$.

13. Heleno, S.A.; Barros, L.; Sousa, M.J.; Martins, A.; Ferreira, I.C.F.R. Study and characterization of selected nutrients in wild mushrooms from Portugal by gas chromatography and high performance liquid chromatography. Microchem. J. 2009, 93, 195-199.

14. Reis, F.S.; Heleno, S.A.; Barros, L.; Sousa, M.J.; Martins, A.; Santos-Buelga, C.; Ferreira, I.C.F.R. Toward the antioxidant and chemical characterization of mycorrhizal mushrooms from northeast Portugal. J. Food Sci. 2011, 76, C824-C830.

15. Fernandes, A.; António, A.L.; Barreira, J.C.M.; Botelho, M.L.; Oliveira, M.B.P.P.; Martins, A.; Ferreira, I.C.F.R. Effets of gamma irradiation on the chemical composition and antioxidant activity of Lactarius deliciosus L. wild edible mushroom. Food Bioprocess Technol. 2013, 6, 2895-2903.

16. Barros, L.; Baptista, P.; Estevinho, L.M.; Ferreira, I.C.F.R. Effect of fruiting body maturity stage on chemical composition and antimicrobial activity of Lactarius sp. mushrooms. J. Agric. Food Chem. 2007, 55, 8766-8771. 
17. Barros, L.; Baptista, P.; Correia, D.M.; Morais, J.S.; Ferreira, I.C.F.R. Effects of conservation treatment and cooking on the chemical composition and antioxidant activity of Portuguese wild edible mushrooms. J. Agric. Food Chem. 2007, 55, 4781-4788.

18. Barros, L.; Baptista, P.; Correia, D.M.; Casal, S.; Oliveira, B.; Ferreira, I.C.F.R. Fatty acid and sugar compositions, and nutritional value of five wild edible mushrooms from Northeast Portugal. Food Chem. 2007, 105, 140-145.

19. Yin, J.Z.; Zhou, L.X. Analysis of nutritional components of 4 kinds of wild edible fungi in Yunnan. Food Res. Develop. 2008, 29, 133-136.

20. Egwin, E.C.; Elem, R.C.; Egwuche, R.U. Proximate composition, phytochemical screening and antioxidant activity of ten wild edible Nigerian mushrooms. Am. J. Food Nutr. 2011, 1, 89-94.

21. Akata, I.; Ergönul, B.; Kalyoncu, F. Chemical compositions and antioxidant activities of 16 wild edible mushroom species grown in Anatolia. Int. J. Pharmacol. 2012, 8, 134-138.

22. Faravin, J.; Foppa, T.; Oliveira, L.P.; Locatelli, C. Avaliação físico química e nutricional do cogumelo Lactatius deliciosus: Aplicabilidade como alimento e ativo farmacológico. Extensão em Foco 2013, 1, 59-64.

23. Kalogeropoulos, N.; Yanni, A.E.; Koutrotsios, G.; Aloupi, M. Bioactive microconstituents and antioxidant properties of wild edible mushrooms from the Island of Lesvos, Greece. Food Chem. Toxicol. 2013, 55, 378-385.

24. Agrahar-Murugkar, D.; Subbulakshmi, G. Nutritional value of edible wild mushrooms collected from the Khasi hills of Meghalaya. Food Chem. 2005, 89, 599-603.

25. Kavishree, S.; Hemavathy, J.; Lokesh, B.R.; Shashirekha, M.N.; Rajarathnam, S. Fat and fatty acids of Indian edible mushrooms. Food Chem. 2008, 106, 597-602.

26. Suortti, T. Stability of necatorin, a highly mutagenic compound from Lactarius. necator mushroom. Food Chem. Toxicol. 1984, 22, 579-581.

27. Mishra, S.R. Morphology of Fungi; Discovery Publishing House: New Delhi, India, 2005.

28. Phillips, R. Mushrooms: A Comprehensive Guide to Mushroom Identification; Macmillan: London, UK, 2006.

29. Heleno, S.A.; Barros, L.; Martins, A.; Queiroz, M.J.R.P.; Santos-Buelga, C.; Ferreira, I.C.F.R. Phenolic, polysaccaridic, and lipidic fractions of mushrooms from Northeastern Portugal: Chemical compounds with antioxidant properties. J. Agric. Food Chem. 2012, 60, 4634-4640.

30. Reis, F.S.; Pereira, E.; Barros, L.; Sousa, M.J.; Martins, A.; Ferreira, I.C.F.R. Biomolecule profiles in inedible wild mushrooms with antioxidant value. Molecules 2011, 16, 4328-4338.

31. Hamano, H. Functional properties of sugar alcohols as low-calorie sugar substitutes. Food Ind. Nutr. 1997, 2, 1-6.

32. Koide, R.T.; Shumway, D.L.; Stevens, C.M. Soluble carbohydrates of red pine (Pinus resinosa) mycorrhizas and mycorrhizal fungi. Mycol. Res. 2000, 104, 834-840.

33. Carvalho, L.M.; Carvalho, F.; Bastos, M.L.; Baptista, P.; Moreira, N.; Monforte, A.R.; Ferreira, A.C.S.; Pinho, P.G. Non-targeted and targeted analysis of toxic and edible mushrooms using gas chromatography-ion trap mass spectrometry. Talanta 2014, 118, 292-303.

34. Öztürk, M.; Tel, G.; Öztürk, F.A.; Duru, M.E. The cooking effect on two edible mushrooms in Anatolia: Fatty acid composition, total bioactive compounds, antioxidant and anticholinesterase activities. Rec. Nat. Prod. 2014, 8, 189-194. 
35. Karlinski, L.; Ravnskov, S.; Kieliszewska-Rokicka, B.; Larsen, J. Fatty acid composition of various ectomycorrhizal fungi and ectomycorrhizas of Norway spruce. Soil Biol. Biochem. 2007, $30,854-866$.

36. Ergönül, P.G.; Akata, I.; Kalyoncu, F.; Ergönül, B. Fatty acid compositions of six wild edible mushroom species. Sci. World J. 2013, doi:10.1155/2013/163964.

37. Gutiérrez, R.M.P. Actividad antimicrobiana de ácidos grasos aislados de Tubifex tubifex. Rev. Mex. Cienc. Farm. 2005, 36, 5-10.

38. Heleno, S.A.; Barros, L.; Sousa, M.J.; Martins, A.; Ferreira, I.C.F.R. Tocopherols composition of Portuguese wild mushrooms with antioxidant capacity. Food Chem. 2010, 119, 1443-1450.

39. Steiner, M. Influence of vitamin E on platelet function in humans. J. Am. Coll. Nutr. 1991, 10, 466-473.

40. Valentão, P.; Lopes, G.; Valente, M.; Barbosa, P.; Andrade, P.B.; Silva, B.M.; Baptista, P.; Seabra, R.M. Quantification of nine organic acids in wild mushrooms. J. Agric. Food Chem. 2007, 53, 3626-3630.

41. Barros, L.; Pereira, C.; Ferreira, I.C.F.R. Optimized analysis of organic acids in edible mushrooms from Portugal by Ultra-Fast Liquid Chromatography and Photodiode Array Detection. Food Anal. Methods 2013, 6, 309-316.

42. Barros, L.; Dueñas, M.; Ferreira, I.C.F.R.; Baptista, P.; Santos-Buelga, C. Phenolic acids determination by HPLC-DAD-ESI/MS in sixteen different Portuguese wild mushrooms species. Food Chem. Toxicol. 2009, 47, 1076-1079.

43. Vaz, J.A.; Barros, L.; Martins, A.; Morais, J.S.; Vasconcelos, M.H.; Ferreira, I.C.F.R. Phenolic profile of seventeen Portuguese wild mushrooms. LWT Food Sci. Technol. 2011, 44, 343-346.

44. Palacios, I.; Lozano, M.; Moro, C.; D’Arrigo, M.; Rostagno, M.A.; Martínez, J.A.; García-Lafuente, A.; Guillamón, E.; Villares, A. Antioxidant properties of phenolic compounds occurring in edible mushrooms. Food Chem. 2011, 128, 674-678.

45. Puttaraju, N.G.; Venkateshaiah, S.U.; Dharmesh, S.M.; Urs, S.M.N.; Somasundaram, R. Antioxidant activity of indigenous edible mushrooms. J. Agric. Food Chem. 2006, 54, 9764-9772.

46. Özyürek, M.; Bener, M.; Güçlü, K.; Apak, R. Antioxidant/antiradical properties of microwave-assisted extracts of three wild edible mushrooms. Food Chem. 2014, 157, 323-331.

47. Münzenberger, B.; Heilemann, J.; Strack, D.; Kottke, I.; Oberwinkler, F. Phenolics of mycorrhizas and non-mycorrhizal roots of Norway spruce. Planta 1990, 182, 142-148.

48. Dogan, H.H.; Aydi, S. Some biological activities of Lactarius vellereus (Fr.) Fr. in Turkey. Pak. J. Biol. Sci. 2013, 16, 1279-1286.

49. Orhan, I.; Üstün, O. Determination of total phenol content, antioxidant activity and acetylcholinesterase inhibition in selected mushrooms from Turkey. J. Food Comp. Anal. 2011, 24, 386-390.

50. Unekwu, H.R.; Audu, J.A.; Makun, M.H.; Chidi, E.E. Phytochemical screening and antioxidant activity of methanolic extract of selected wild edible Nigerian mushrooms. Asian Pac. J. Trop. Dis. 2014, 4, S153-S157.

51. Association of Official Analytical Chemists. Official Methods of Analysis, 16th ed.; AOAC: Arlington, VA, USA, 1995. 
52. Abreu, R.M.V.; Ferreira, I.C.F.R.; Calhelha, R.C.; Lima, R.T.; Vasconcelos, M.H.; Adega, F.; Chaves, R.; Queiroz, M.J.R.P. Anti-hepatocellular carcinoma activity using human HepG2 cells and hepatotoxicity of 6-substituted methyl 3-aminothieno[3,2-b]pyridine-2-carboxylate derivatives: In vitro evaluation, cell cycle analysis and QSAR studies. Eur. J. Med. Chem. 2011, 46, 5800-5806.

Sample Availability: Samples of the mushrooms are available from the authors.

(C) 2014 by the authors; licensee MDPI, Basel, Switzerland. This article is an open access article distributed under the terms and conditions of the Creative Commons Attribution license (http://creativecommons.org/licenses/by/4.0/). 